\title{
Health risk assessment for sewage sludge applied to land in France
}

\author{
L. Déléry ${ }^{1}$, G. Gay ${ }^{1}$, S. Denys ${ }^{1}$, H. Brunet ${ }^{2}$, I. Déportes ${ }^{3}$, \\ A. Cauchi ${ }^{4}$ \& M. Aupetitgendre ${ }^{4}$ \\ ${ }^{I}$ National Institute for Industrial Environment and Risks, France \\ ${ }^{2}$ Professional Association for agricultural recycling, France \\ ${ }^{3}$ French Agency for the Environment and Energy Management, France \\ ${ }^{4}$ Professional association for water distribution, France
}

\begin{abstract}
Chemical and microbial health risks associated with the application of municipal and industrial sewage sludge to agricultural land were addressed in order to set guidelines within the French legislative context. The chemical part was a quantitative risk assessment study based on the simplified source-pathway-receptor event tree approach. The selected chemicals were those quoted in the French legislation. Several receptors were considered: population consuming vegetables and meat impacted by the sludge application, nearby populations also walking close to fields receiving sludge, farmers plowing such fields, and future residents consuming their own vegetables on former fields. The assumptions and the uncertainties of the approach were discussed. The first quantitative results led to acceptable risk levels, and allowed one to identify the major exposure pathways. The microbial part was a feasibility study based on a literature review. In spite of many uncertainties, a preliminary quantitative risk assessment case study for Enterovirus, Salmonella, E. coli $0157: \mathrm{H} 7$ and Cryptosporidium parvum was developed in order to identify the critical points of the process and to judge its relevance within the national context. Uncertainties of the quantitative risk approach were discussed in detail and led to the proposal of qualitative guidelines based on an event tree, due to the current state of knowledge.
\end{abstract}

Keywords: sewage sludge, chemical and microbial health risk assessment, France. 


\section{Introduction}

In France, municipal and industrial sludges from sewage treatment works are regarded as waste within the existing regulation (French law $\mathrm{n}^{\circ} 75-633$ of July $15,1975)$. The fertilising properties of these wastes have been recognised for many years and their application on agricultural lands for 30 years in France is considered as an environmental and economical sustainable management [1]. Because of the presence of chemical contaminants and pathogens in sludge, precaution measures are taken with respect to the practice of spreading to guarantee food safety and the preservation of soils and other environmental compartments. They are framed by the French law n92-3 of January 3, 1992 known as law on water and law $\mathrm{n}^{\circ} 76-663$ of July 19, 1976 related to the classified installations for the environmental protection, and soon by a European directive on sewage sludge (currently under development). Municipal and industrial sewage treatment works subjected to French authorisation have to fulfil a study relative to the human health impact of sludge spreading. However no guideline to carry out such health risk assessment is available so far.

The objectives of the present study were the development of health risk assessment methodologies for both chemical and microbiological hazards. For the chemical part, the methodology was developed on two real sites. For the microbial part, as there are no limit values for pathogen concentrations (except for sludges that undergo treatments to reduce Salmonella, Enterovirus and helminth eggs content and for which there are no distance or period restrictions), a feasibility study based on a literature review was undertaken.

\section{Chemical health risk assessment}

The chemical health risk assessment methodology was developed with respect of the general risk assessment principles defined by US-EPA and already used in other French methodologies dedicated to other environmental media (contaminated soils for instance). In this specific case, the human health risk assessment was considered after 10 years of sludge application for a given area, this time frame being considered to be the duration over which sludge application is allowed by the authorisation procedure. Frequency of sludge spreading on a same plot is defined by the legislation and assumed to be, for a same plot, every three years.

\subsection{A four steps methodology}

The description of the methodology set up can be done according to four steps mentioned below:

- determination of site characteristics,

- evaluation of toxic effects for the selected substances,

- exposure evaluation,

- risk quantification. 


\subsubsection{Determination of site characteristics}

The methodology developed here is based on a site-specific approach. The risk assessor has first to evaluate the site properties and technical methods of spreading which will lead to an accurate risk quantification. Among these characteristics, sludge composition (type of pollutant and concentrations), pedology (texture, $\mathrm{pH}$, etc.), agricultural practices (cultures and spatial and temporal distribution, sludge application, etc.) have to be properly known to define which substances will be selected during the quantification step. It was defined that each substance mentioned in the legislative text should be selected to assess potential risks of sewage sludge spreading on agricultural lands, these substances currently being in the French legislation heavy metals (cadmium, chromium, copper, mercury, nickel, selenium, lead and zinc), polycyclic aromatic hydrocarbons (fluoranthen, benzo[b]fluoranthen, benzo[a]pyren) and polychloro-bi-phenyls. Critical issue of this first step is the definition of a conceptual scheme defining substances, exposure pathway and receptors that have to be considered for the risk quantification procedure.

\subsubsection{Evaluation of toxic effects for the selected substances}

Toxic effects have to be described for each effect of the studied substance (threshold or non-threshold effects). A thorough description of the different organs on which substances have an effect has to be done. When available, quantitative data about the effects of the substances on Humans will be selected among data available into the international toxicological databases. These toxicological reference values (TRV) will be used for risk quantification.

\subsubsection{Exposure evaluation}

The objective of this step is the evaluation of the dose of exposure (ED) for each receptor and each exposure pathway. This requires the estimation of the substance concentration in the soil on which sludge is spread (source of contamination), the values of parameters needed to estimate the transfer of substances to Humans (through either direct or indirect contact) and the values of parameters concerning daily food ingestion, space and time budget for each receptor.

Receptors and exposure pathways that have to be considered by the risk assessor are described below (table 1).

Table 1: Receptors and exposure pathways.

\begin{tabular}{|l|c|c|c|c|}
\hline & Farmers & Inhabitants & $\begin{array}{l}\text { General } \\
\text { Population }\end{array}$ & $\begin{array}{l}\text { Inhabitants on } \\
\text { former plots }\end{array}$ \\
\hline Direct Contact & $\mathbf{x}$ & $\mathbf{x}$ & & $\mathrm{x}$ \\
\hline Soil ingestion & $\mathrm{x}$ & $\mathrm{x}$ & & $\mathrm{x}$ \\
\hline Soil inhalation & $\mathrm{x}$ & $\mathrm{x}$ & & $\mathrm{x}$ \\
\hline Dermal contact with soil & $\mathrm{x}$ & $\mathrm{x}$ & & $\mathrm{x}$ \\
\hline Indirect Contact products & $\mathrm{x}$ & $\mathrm{x}$ & $\mathrm{x}$ & $\mathrm{x}$ \\
\hline $\begin{array}{l}\text { Agricultural } \\
\text { consumption }\end{array}$ & $\mathrm{x}$ & $\mathrm{x}$ & $\mathrm{x}$ & $\mathrm{x}$ \\
\hline Contaminated water contact & & & \\
\hline
\end{tabular}


In predictive scenarios, concentration of each substance has to be calculated theoretically considering sludge dilution in a volume of agricultural soil, this volume depending on legislation, soil density and depth of spreading.

\subsubsection{Risk quantification}

This final step allows one to calculate, for threshold and non-threshold effects of each substance, the risk for each identified exposure pathway. For each route of exposure (ingestion, inhalation, dermal contact) addition of risk values (RV) has to be carried out for substances having effects on the same organs.

For the threshold effects, the risk value is obtained according to eqn (1):

$$
\mathrm{RV}_{\text {threshold effect }}=\mathrm{ED} / \mathrm{TRV}
$$

whereas for the non-threshold effects, the risk value is obtained according to eqn (2):

$$
\mathrm{RV}_{\text {non-threshold effect }}=\mathrm{ED} * \mathrm{TRV}
$$

Analysis of these values by the risk assessors has to be done concomitantly to the examination of uncertainties related to the methodology and phenomena taken into account when modelling the fate of pollutants from soils containing sludge to Man. It is usually considered that $\mathrm{RV}_{\text {threshold effect }}<1$ and $\mathrm{RV}_{\text {non-threshold effet }}<10^{-5}$ are acceptable risks values.

The methodology described before was applied to assess the chemical health risks on two French sites. One site was dedicated to the spreading of industrial sludge whereas urban sludge was amended on the other site. Exposure pathways were also different between the two cases: the first case had to consider the soil-(plant)-grazing animal-human pathway whereas this way of exposure was not accurate for the second scenario as lands were entirely dedicated to cereals cultivation.

For the two sites and whatever the receptors, risks values were below 1 for the threshold-effect and below $10^{-5}$ for the non-threshold effects showing that, according to our methodology and under the different assumptions made for the calculation, the spreading of sewage sludge on agricultural lands was an acceptable practice. For the two cases, the more significant risks were associated with the consumption of plants harvested on amended soils.

\section{Microbial health risk assessment}

Since the first French report on microbial health risks for sewage sludge [2], French research studies [3, 4] and thesis [5-13] were carried out. The first objective of this work was the analysis of the current knowledge on all the steps of the risk assessment approach. The second objective was the evaluation of the feasibility to implement a quantitative assessment of the risks of infection to humans. 
Reports of this type have been published in particular in the United Kingdom [14] and the United States [15], so it appeared interesting to develop a case study based on data adapted to the French context. Taking into account the relevance to apply this exercise within the framework of national studies resulted in the setting of qualitative guidelines.

\subsection{Literature review}

This part of the study provided current available data on loads of pathogens in sludge, their sensitivity to sludge treatments and to storage, their survival in soil and their transport to environmental media (soil, water and air) after spreading, data on other sources of pathogens in the agricultural environment, epidemiological data (linked to direct exposure to sludge, wastewater and sludge composts as well as a synthesis on environmental waterborne outbreaks in France) and their health outcomes. This review also allowed the main gaps in knowledge to be highlighted.

\subsubsection{Major findings}

During 30 years of practice in France, no environmental epidemic outbreak linked with the spreading of sludge was detected. We found a few epidemiological studies conducted specifically for sludge exposure in our literature review [16]. The examination of the whole available epidemiological data in France indicated that ingestion of contaminated drinking water without any proven link with land spreading of sludge is to the present day the only way of exposure blamed in the waterborne outbreaks of environmental origin.

For ten years, French studies collected data on detection and quantification of certain pathogenic agents (helminth eggs, Giardia spp. cysts, Salmonella, Enterovirus, VHA, verotoxic E. coli, Listeria spp.) in sewage sludge. Helminth Ascaris $s p$. has practically disappeared in humans and pigs in metropolitan France because of hygienic rules and industrial breeding. Taenia saginata probably represents the last principal parasitic issue in human and animal health since it is practically found in all the sludges analyzed under moderate climates [17]. The review also shows that contamination of raw municipal sludge is quasi systematic. Some pathogens are little studied (Cryptosporidium sp., other protozoa like Balantidium sp., Campylobacter sp., Yersinia spp., Vibrio spp., shigatoxins producing $E$ coli, etc.) or are not studied at all in sludges (Adenovirus, Calicivirus, Astrovirus, mycobacteria, microsporidia...). Only 2 studies on the contamination of raw French slaughterhouses sludge were found $[18,19]$.

In France, there are some data on the contamination of treated municipal sludge (Enterovirus, Listeria sp., Giardia cysts, helminths eggs) but not on those of slaughterhouses or dairies sewage treatment works. All in all, the advanced treatments for the reduction of pathogens recommended by the European Community in 2001 [20] are: composting, thermal drying, thermophilic digestion, followed heat treatment followed by digestion and liming.

The French standardized methods for the analysis of pathogens in sludge are only available for helminth eggs, Salmonella and soon for the Enterovirus. The 
European project Horizontal is intended to supplement currently available tools for sampling and analysis for the sludge matrix.

Many factors influence the survival of pathogens in the environment. Most of the time, survival is decreasing within 2 months because of the adverse conditions (dessication, temperature, natural competition) in the environmental media.

The pathogens of small size (virus, bacteria and some protozoa) can be found in bioaerosols [21] formed by the spreading with spray tanker or spray irrigation application of liquid sludge in windy conditions.

Water constitutes the main pathway of pathogens dissemination in the environment. However, in France, contamination of water is reduced by the respect of the regulation (distances of land spreading from sensitive uses). Moreover, taking into account the French regulated times of spreading, it is not very probable to find pathogens on plants grown on agricultural soils spread with sludge and the role of animals grazing on those sites in the transmission of pathogens with man is reduced.

\subsubsection{Research needs}

According to our findings, the principal needs of data concern: i) the determination of the species of the biological agents in sludge (salmonella, campylobacter spp., cryptosporidium sp., etc.) as finer knowledge would make it possible to identify the human, animal, environmental origin of the pathogens ii) the presence, quantification and virulence of pathogens in raw and treated municipal sludge (endotoxins, Staphylococcus aureus, Vibrio spp, viruses rotavirus, calicivirus, adenovirus, etc. -, pathogenic E coli, Pseudomonas aeruginosa Cryptosporidium spp., mycobacteria, microsporidia, etc.) and in industrial sludge (Pseudomonas spp., Listeria monocytogenes, Campylobacter spp., Salmonella) iii) the determination of presence and ecology of Legionella and its methods of detection in sludge; iv) the construction of a data base on the survival and transport of pathogens (and in particular of viruses) in the environment (soil and plants); v) the human exposure to bioaerosols and composts of sludge at the time of spreading on land.

\subsection{Preliminary risk assessment}

In spite of many uncertainties linked to the state of knowledge, a preliminary quantitative risk assessment case study was developed for liquid raw sludge in order to identify the critical points of the process and to judge its relevance within the national context of health impact studies.

\subsubsection{Rationale for selecting pathogens}

From a list of principal pathogens of concern in sewage sludge established by ADEME [22] and EPA [23], Enterovirus, Salmonella, E coli $\mathrm{O} 157$ :H7 and Cryptosporidium parvum were selected on two criteria: existing data on load of pathogen in sludge or sewage water in France and on dose-response curves by ingestion. Table 1 presents a summary of those data for each selected pathogen. 
Table 2: $\quad$ Summary of data used for microbial assessment.

\begin{tabular}{|l|l|l|l|l|}
\hline & $\begin{array}{l}\text { Load of pathogens in } \\
\text { sludge }\end{array}$ & & $\begin{array}{l}\text { Probability of infection (with N } \\
\text { dose of pathogen) }\end{array}$ & \\
\hline Enterovirus & $280 \mathrm{IU} / \mathrm{g}$ DS & {$[9]$} & $\mathrm{P}(\mathrm{N})=1-(1+\mathrm{N} / 0,42)^{-0,26}$ & {$[3]$} \\
\hline Salmonella & $10^{4} \mathrm{CFU} / \mathrm{g}$ DS & {$[3]$} & $\mathrm{P}(\mathrm{N})=1-(1+\mathrm{N} / 51,45)^{-0,1324}$ & {$[24]$} \\
\hline E. coli O157:H7 & $0,6 \mathrm{CFU} / \mathrm{g}$ DS & $*$ & $\mathrm{P}(\mathrm{N})=1-(1+\mathrm{N} / 1,001)^{-0,05}$ & {$[25]$} \\
\hline $\begin{array}{l}\text { Cryptosporidium } \\
\text { parvum }\end{array}$ & 100 oocysts/g DS & $*$ & $\mathrm{P}(\mathrm{N})=1-\exp (-\mathrm{N} / 238)$ & {$[3]$} \\
\hline
\end{tabular}

* calculated from an event tree with an isolation percentage during surveillance at slaughterhouses of 1\% for E. coli $\mathrm{O} 157: \mathrm{H} 7$ and from a load in sewage water of 30 oocysts/L for Cryptosporidium.

\subsubsection{The conceptual model}

The conceptual model was based on the simplified source-pathway-receptor event tree approach. Two receptors and three exposure pathways were considered: farmers plowing and ingesting dust from soil receiving sludge and nearby populations consuming their own vegetable products contaminated either by biological aerosols from the land receiving sludge either by erosion of amended soil. Many worst case assumptions were considered based on experts' judgment. The main assumptions are presented in figure 1 .

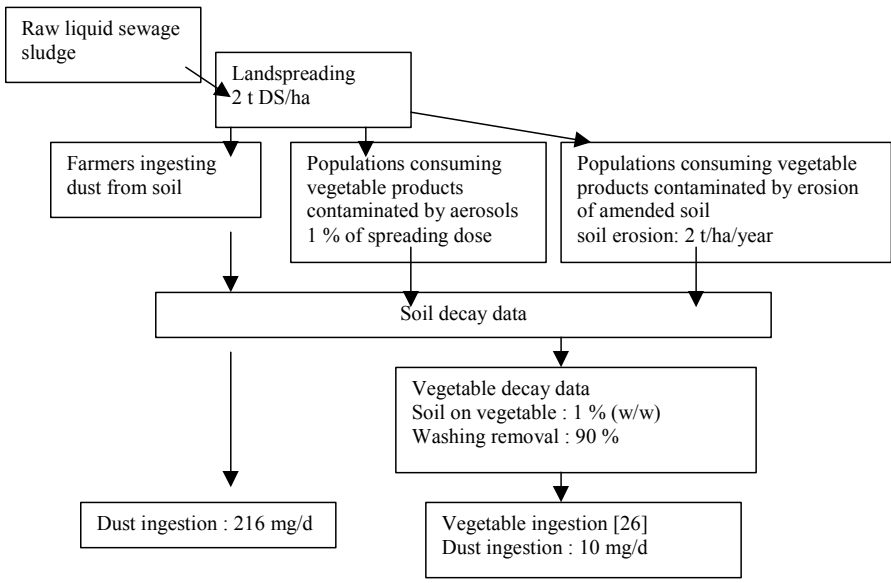

Figure 1: $\quad$ Exposure event tree.

\subsubsection{Results}

Under main worst case assumptions and in the current state of knowledge, preliminary results for the liquid raw sludge spreading showed that: calculated exposures for both receptors are very weak (always lower than 1 pathogen/d); whatever pathogen is considered, the risks to have at least one infection over the exposure time is in decreasing order: population/biaerosol $>$ farmer $>$ 
population/erosion; whatever receptor is considered, the risks to have at least one infection over the exposure time is in decreasing order: Enterovirus $>$ Salmonella $>$ Cryptosporidium parvum $>$ E coli $\mathrm{O}$ 157: $\mathrm{H} 7$.

\subsubsection{Uncertainty}

This preliminary quantitative risk assessment was developed on a great number of working assumptions surrounded by uncertainty. Indeed, in the absence of sufficient data, values considered as realistic or worst case were used following a consensus of experts.

The main sources of uncertainty in the model are: i) the estimation of the pathogen loading in sludge that is directly related to the natural heterogeneity and to uncertainties of microbiological methods of analysis ii) the doseresponses relations that are rare in the literature, mostly available for ingestion and not built for the sludge matrix, in addition the existence of an acquired immunity or the genetic specificity of certain individuals are not taken into account because it is not easily quantifiable iii) the modelling of pathogens decay in soil environment and vegetables is very simplified and there is currently no experimental evidence to support the pathogens concentration results iv) the exposure scenarios used for both receptors correspond to the worst case situations (for example use of an open tractor for the farmer which increases significantly the quantity of dust ingested, and for the residents, use of uncertain modelling of bioaerosols deposition because of the lack of experimental data) which are not representative of the "normal" conditions of spreading in France vi) an important phenomenon (losses in the environment at the time of the rain) was not taken into account.

\subsection{Recommended guidelines}

The feasibility study enabled us to propose guidelines based on a qualitative analysis of the microbial risks and control measures. The analysis can be carried out according to the decisional tree that includes the data needed to describe sludge spread to land, the exposed populations and the preventive measures. Measures of risk reduction are based on solutions proposed by the French regulation: either a reduction of the sludge pathogens load (hygienized sludges) or a reduction of the human exposures (for other sludges).

\section{Acknowledgements}

This work was supported by funding from ADEME, SYPREA, SPDE and INERIS. We cordially address our thanks to all experts that contributed to it.

\section{References}

[1] Agence de l'eau Rhin-Meuse, Audit environnemental et économique des filières d'élimination des boues d'épuration, cahier $\mathrm{n}^{\circ} 70$, études des agences de l'eau, pp.124, 1999. 
[2] CSHPF, Risques sanitaires liés aux boues d'épuration, Technique \& Documentation, pp. 1-18, 1998.

[3] AGHTM, Impact du futur projet européen sur la valorisation des boues en agriculture - campagne d'analyses sur 60 boues de STEP, pp. 139, 2002.

[4] NANCIE, Micropolluants organiques et germes pathogènes dans les boues d'eaux résiduaires, programme national, pp. 250, 2000.

[5] Cardiergues, B., Boues d'épuration et microorganismes pathogènes: influence de différents traitements et $d u$ stockage, thèse de l'université Henri Poincaré, Nancy, pp. 240, 2000.

[6] Garrec, N., Détection et étude de la survie de Listeria monocytogenes dans les boues d'épuration destinées à l'épandage, thèse de l'Ecole doctorale d'Angers, pp.169, 2003.

[7] Gaspard, P., Contamination parasitaire dans l'environnement: prospective pour un gestion des risques sanitaires, thèse de l'université Henri Poincaré, Nancy, pp. 228, 1995.

[8] Madeline, M., Evaluation du risque sanitaire (parasitaire et virologique) des boues résiduaires urbaines en agriculture et des eaux épurées dans l'environnement, thèse de l'université de Caen, pp. 223, 2003.

[9] Monpoého, S., Quantification génomique de 2 virus entériques (entérovirus et HAV) dans les boues de stations d'épuration. Estimation de l'impact sanitaire lié à leur valorisation agricole, thèse de la Faculté de Pharmacie de Nantes, pp. 177, 2001.

[10] Moussavou-Boussougou, M.N., Epandage des boues d'épuration urbaine et des lisiers sur les pâturages: risque parasitaire pour les ruminants, thèse de Sciences, Tours, pp. 139, 2004.

[11] Paillard, D., Prévalence et résistance aux antibiotiques de Listeria spp. dans les effluetns de stations d'épuration, thèse de l'université de Pau, 2003.

[12] Thiriat, L., Valorisation agricole des boues résiduaires: dénombrement des kystes de Giardia sp. et estimation de leur impact sur le risque sanitaire, thèse de l'université Henri Poincaré de Nancy, pp. 231, 1998.

[13] Vansteellant, J., Evaluation des risques de contamination microbiologique liés aux épandages de matières organiques sur prairie de montagne, thèse de l'université de Savoie, pp. 172, 2004.

[14] UKWIR, Pathogens in biosolids- Microbiological risk, UK Water Industry Research, Environmental Agency, DEFRA, pp. 125, 2003.

[15] WERF, A dynamic model to assess microbial health risks associated with beneficial uses of biosolids: phase 1, Water Environment Research Foundation, 2003.

[16] NRC, (eds). Biosolids applied to land: advancing standards and practices, The national Academies Press: Washington DC, 2002.

[17] Cabaret, J., Geerts S. et al., The use of urban sewage sludge on pastures: the cysticersosis threat, Vet. Res., 33, pp. 575-597, 2002. 
[18] INRA-ENVT, Bactéries pathogènes dans les effluents d'abattoirs: aide à l'évaluation des risques pour la santé publique, Toulouse, équipe environnement de l'UMR 960, pp. 72, 2002.

[19] Hydro-M, Microbiologie et environnement: les effluents de la filière viande, INTERBEV/ FNEAP - AELB/AESN, pp. 9, 2004.

[20] European Community, Evaluation of sludge treatments for pathogen reduction, pp. 44, 2001.

[21] Brooks, J., National Study on Residential Impact of Biological Aerosols from Land Application of Biosolids. Journal of Applied Microbiology, 99, pp. 310-322, 2005.

[22] ADEME, Les agents biologiques d'intérêt sanitaire des boues d'épuration urbaines, Guides et cahiers techniques Connaître pour agir, pp. 180, 1999.

[23] USEPA, Control of pathogens and vector attraction in sewage sludge, Office of Research and Development, pp. 177, 1999.

[24] WHO/FAO, Risk Assessments of Salmonella in Eggs and Broiler Chickens, Microbiological Risk Assessment Series-2, pp. 50, 2002.

[25] Teunis P., Dose response for infection by Escherichia coli O157: H7 from outbreak data, Risk analysis, 24(2), pp. 401-407, 2004.

[26] ADEME, Réhabilitation des sites et sols pollués Ciblex banque de données, Cédérom - Co-édition: IRSN, Réf. 4773, 2003. 